\title{
ANALGESIC EFFECT OF ETHANOLIC EXTRACT OF SEEDS AND LEAVES OF CORIANDRUM SATIVUM ON SWISS ALBINO MICE
}

\author{
Chandrajeet Kumar Yadav, ${ }^{1}$ Poonam Tiwari, ${ }^{2}$ Roshan Mehta, ${ }^{1}$ Amit Kumar Shrivastava, ${ }^{1}$ Anjan Palikhey
}

\begin{abstract}
INTRODUCTION

Pain has been described by the International Association for the Study of Pain as an unpleasant sensory and emotional experience associated with actual or potential tissue damage, or described in terms of such damage. Although NSAIDs and OPIOIDs are available for the treatment, still pain (chronic) is major problem. The present study was designed to study the analgesic effect of ethanolic extract of Coriandrum sativum using hot plate method and acetic acid induced writhing method in experimental animals (Swiss Albino mice).
\end{abstract}

\section{MATERIAL AND METHODS}

The analgesic effect of leaves and seeds of Coriandrum sativum was assessed using Eddy's hot plate method and acetic acid induced writhing method in Swiss Albino mice. The animals were treated with the ethanolic extract of leaves and seeds of Coriandrum sativum administered orally at two doses of $100,500 \mathrm{mg} / \mathrm{kg}$ body weight after electric heat and acetic acid induced pain in mice.

\section{RESULTS}

The study showed that ethanolic extract of leaves and seeds of Coriandrum sativum presented significant $(p<0.05)$ and $(p<0.05)$ analgesic activity in mice simultaneously. The data were analyzed by one-way ANOVA followed by Dunette's multiple comparison test. The results demonstrate that ethanolic extract of leaves and seeds of Coriandrum sativum has got analgesic potential.

\section{CONCLUSION}

The results demonstrate that ethanolic extract of leaves and seeds of Coriandrum sativum has got significant analgesic effect.

\section{KEYWORDS}

Analgesic effect, Coriandrum sativum, Ethanolic extract, Pain.

${ }^{1}$ Department of Pharmacology, Universal College of Medical Sciences, Bhairahawa, Rupandehi, Nepal

${ }^{2}$ Department of Pharmacy, Universal College of Medical Sciences, Bhairahawa, Nepal

DOI: https://doi.org/10.3126/jucms.v9i02.42008

\author{
For Correspondence \\ Chandrajeet Kumar Yadav \\ Department of Pharmacology \\ Universal College of Medical Sciences \\ Bhairahawa, Nepal \\ Email: chandrajity2046@gmail.com
}




\section{INTRODUCTION}

Pain has been described by the International Association for the Study of Pain as an "unpleasant sensory and emotional experience associated with actual or potential tissue damage, or described in terms of such damage". ${ }^{.}$Chronic pain and the inflammatory diseases are one of the major health problems in the world. ${ }^{2}$ Several factors including sociocultural, psychological and biological conditions have important roles in pain perception. Although pain is a reaction of the body to harmful stimuli, it is a protective early warning system. In medical diagnosis, pain is regarded as a symptom of an underlying condition. 'Pain is a vital function of the human body, involving nociceptors and the central nervous system (CNS) to transmit messages from noxious stimuli to the brain.

Types of pain: Simply, pain can be divided into two typesacute pain and chronic pain.

a. Acute pain: Acute pain is pain of sudden onset; lasting for hours to days and disappears once the underlying cause is treated. Acute pain has a clear cause. It could result from any illness, trauma, surgery or any painful medical procedures. Acute pain is beneficial for us as it signals that something is wrong in our body and motivates us to get help soon. Example of acute pain includes- headache, heartache, muscle sprain, bone fracture, cuts in skin etc.

b. Chronic pain: Chronic pain is the pain that starts as an acute pain and continues beyond the normal time expected for resolution of the problem or persists or recurs for various other reasons. It is not the rapeutically beneficial to the patient. ${ }^{3}$

Analgesic drugs are used in single or in combination to affect peripheral or central nervous system (CNS) to decrease pain sensation. Analgesics are drugs that relieve pain without significantly altering consciousness. They relieve pain without affecting its cause. There are two groups of analgesics:

Opioid (Narcotic analgesics)

Non- opioid (Non-steroidal anti-inflammatory drugs)

Opioids are substances that, when reaching opioid receptors, have effects similar to those of morphine. Medically they are primarily used for pain relief, including anesthesia. Other medical uses include suppression of diarrhea, replacement therapy for opioid use disorder, reversing opioid overdose as well as suppressing cough. Morphine is the most important alkaloid of opium - the dried juice obtained from the capsules of Papaver somniferous. Opium contains many other alkaloids, such as codeine, thebaine, papaverine etc. Mechanism of action of opioids: Morphine and other opioids produce their actions by interacting with various opioid receptors - mu $(\mu)$, kappa $(\kappa)$ and delta $(\delta)$. They inhibit the release of neurotransmitters from the primary afferent terminals in the spinal cord as well as activate the descending inhibitory controls in the brain. This results in the sensation of pain relief as well as a relaxing and sedative effect. ${ }^{4}$

Nonsteroidal anti-inflammatory drugs (NSAIDs) are among the most widely used medications due to their efficacy for a wide range of pain and inflammatory conditions. ${ }^{5}$ However, the long-term administration of NSAID may induce gastrointestinal ulcers, bleeding, and renal disorders due to their nonselective inhibition of both constitutive (COX-and inducible (COX-2) isoforms of the cyclooxygenases enzymes. ${ }^{6}$ Therefore, new anti-inflammatory and analgesic drugs lacking those effects are being searched all over the world as alternatives to NSAIDs and opiates. ${ }^{7.8}$ The research into plants with alleged folkloric use as pain relievers, antiinflammatory agents, should therefore be viewed as a fruitful and logical research strategy in the search for new analgesic and anti-inflammatory drug. The plant derived natural products such as flavonoids, sterols, polyphenols, alkaloids, tannins and terpenes have gained importance in recent years due to their wide range of pharmacological activities ${ }^{9}$. Coriandrum sativum Linn. (Apiaceae/ Umbelliferae) is a native plant from southern Europe and Southwestern Asia that has been naturalized in North America and acclimatized in many countries with a temperate climate. It is popularly known as coriander, Chinese parsley, or cilantro, and it has been used to add flavor, color and nutritional properties to food in many Asian countries. ${ }^{10}$ Parts of $C$. sativum $(\mathrm{CS})$ have been used to treat many diseases and conditions, such as rheumatism/ joint pain, indigestion/ gastrointestinal disorders, anxiety etc. Its antioxidant, anti-diabetic, anticancer properties have previously been reported ${ }^{11}$.

This study was conducted to explore analgesic effect of leaves and seeds of Coriandrum sativum was assessed using hot plate method and acetic acid induced writhing method in Swiss albino mice.

\section{MATERIAL AND METHODS}

The analgesic effect of leaves and seeds of Coriandrum sativum was assessed using Eddy's hot plate method and acetic acid induced writhing method in Swiss albino mice. The animals were treated with the ethanolic extract of leaves and seeds of Coriandrum sativum administered orally at two doses of 100, $500 \mathrm{mg} / \mathrm{kg}$ body weight after electric heat and acetic acid induced pain in mice. This study was carried out from October 2020 to May 2021 after the taking approval from Institutional Review Committee of Universal College of Medical Sciences, IRC No. (UCMS/IRC/019/20) at Department of Pharmacology of Universal College of Medical Sciences, Bhairahawa, Rupandehi, Nepal. 


\section{Animals}

Swiss Albino mice (Mus musculus) either sex weighing 23-32 $\mathrm{g}$ (four weeks of age) were kept in the animal house in the Department of Pharmacology at Universal College of Medical Sciences for the experimental purpose. All the animals were housed in clean polypropylene cages and were maintained at standard conditions of temperature $\left(25 \pm 1^{\circ} \mathrm{C}\right)$ and 12:12 hour light/ dark cycles. They were fed with standard pellet diet and had free access to water ad libitum.

\section{Plant material}

The aerial parts of the leaves and seeds of Coriandrum sativum were collected from Ranigaun, Bhairahawa, Rupandehi, Nepal. The selected plant was identified and authenticated by Mr. Rukmagat Pathak, Assistant Professor, Department of Soil and Environment Science, TU, IAAS, Paklihawa, Rupandehi on date 4/04/2021. All other chemicals used in the study are of AR grade.

\section{Preparation of extract}

The aerial parts of the leaves and seeds of Coriandrum sativum collected were washed thoroughly with water and airdried under shade at room temperature. Then, the dried plant materials were chopped into small pieces and finely ground to give powder form of crude drug. The drug was extracted in the ratio 1:6 using ethanol as solvent by continuous hot percolation with the help of Soxhlet apparatus. The duration of extraction was 48 hours. The extract was reduced to dryness using rotary apparatus. Lastly, the percentage yield of extract was calculated. The seed and leaves were extracted separately using the same method. ${ }^{1213}$

$$
\begin{gathered}
\text { Yield }(\text { Leaves })=\frac{\text { weight of dried leaves extract }}{\text { weight of dried powder used to be extracted }} \times 100 \\
\text { Yield }(\%)=\frac{11.56}{100} \times 100=11.56 \\
\text { Yield }(\text { Seeds })=\frac{\text { weight of dried seeds extract }}{\text { weight of dried powder used to be extracted }} \times 100 \\
\text { Yield }(\%)=\frac{9.36}{100} \times 10=9.36
\end{gathered}
$$

\section{Phytochemical screening}

Phytochemical screening was carried out for the determination of different secondary metabolites (Carbohydrate, glycosides, saponin, sterols, tannins, terpenoids, flavonoids and alkaloids) present in the leaves and seed extract of Coriandrum sativum. ${ }^{14}$

\section{Acute oral toxicity studies (oppts 870.1100)}

The acute oral toxicity study was performed according to the OPPTS (Office of Prevention, Pesticides, and Toxic Substances) guidelines.

\section{Dose selection}

Lethal dose $5000 \mathrm{mg} / \mathrm{kg}$ selected and two doses of $100 \mathrm{mg} / \mathrm{kg}$ and $500 \mathrm{mg} / \mathrm{kg}$ body weight of ethanolic extract of Coriandrum sativum leaves and seeds was selected as low dose and high dose as per the acute oral toxicity studies. ${ }^{15}$

\section{Experimental design}

The mice were randomly divided into four groups each for leaves and seeds extract. So total groups are six including negative control and standard ( $\mathrm{n}=5$ mice per group). Thus, 30 mice were used for the evaluation of analgesic effect of

\begin{tabular}{|c|c|c|c|}
\hline \multicolumn{2}{|c|}{ Leaves extract } & \multicolumn{2}{|c|}{ Seed extract } \\
\hline Animal Group & Dose & Animal Group & Dose \\
\hline Negative control & $\begin{array}{l}\text { Disease induced and } \\
\text { vehicle only }\end{array}$ & Negative control & $\begin{array}{l}\text { Disease induced and } \\
\text { ehicle only }\end{array}$ \\
\hline $\begin{array}{l}\text { Standard (Diclofenac } \\
\text { sodium) }\end{array}$ & $10 \mathrm{mg} / \mathrm{kg}$ & $\begin{array}{l}\text { Standard (Diclofenac } \\
\text { sodium) }\end{array}$ & $10 \mathrm{mg} / \mathrm{kg}$ \\
\hline Test-1 & $100 \mathrm{mg} / \mathrm{kg}$ & Test -1 & $100 \mathrm{mg} / \mathrm{kg}$ \\
\hline Test-2 & $500 \mathrm{mg} / \mathrm{kg}$ & Test-2 & $500 \mathrm{mg} / \mathrm{kg}$ \\
\hline
\end{tabular}
Coriandrum sativum leaves and seed (Table 1).

Table 1. Experimental design groups each for leaves and seeds extract

\section{Eddy's hot plate method}

To assess nociceptive responses, hot plate method was used. The mice were placed on the hot plate with temperature setting controlled at $55 \pm 0.2^{\circ} \mathrm{C}$. Cut-off time will be 30 seconds. Nociceptive or pain response was defined as licking forepaws or moving hind paws. Time duration between placing the animals on hot plate and licking fore paws or moving hind paws was considered as the reaction time. The hot plate test will be performed as a base record $10 \mathrm{~min}$ before injection of the drugs and consequently it was repeated five times, every $10 \mathrm{~min}$ after injection. Analgesic effects of the extracts (both leaf and seed) or vehicle was calculated as maximal possible effect(MPE). ${ }^{16}$

$$
\text { MPE } \%=\frac{(\text { Test response time }- \text { Basal response time })}{\text { Cutoff time }- \text { Basal response time }} \times 100
$$

\section{Acetic acid induced writhing method}

The analgesic effect on the samples was evaluated using acetic acid induced writhing method in mice. In this method, acetic 
acid was administered intra-peritoneally to the experimental animals to create pain sensation. As a positive control, diclofenac sodium was used to serve the purpose. The plant extracts were administered orally in two different doses (100 and $500 \mathrm{mg} / \mathrm{kg}$ body weight) to the Swiss albino mice after an overnight fast. Test samples and vehicle administered orally 30 minutes prior to intraperitoneal administration of $0.7 \% \mathrm{v} / \mathrm{v}$ acetic acid solution $(0.1 \mathrm{ml} / 10 \mathrm{~g})$ but diclofenac sodium was administered 15 minutes prior to acetic acid injection. Then the animals were placed on an observation table.

Each mouse of all groups was observed individually for counting the number of writhing they made in 15 minutes commencing just five minutes after the intraperitoneal administration of acetic acid solution. The number of writhes in each treated group will be compared to that of a control group where Diclofenac sodium $(10 \mathrm{mg} / \mathrm{kg})$ will be used as a reference substance (positive control). ${ }^{16}$ Anti-nociception (analgesia) will be expressed as the reduction of the number of abdominal constrictions between control animals and mice pretreated with extracts.

\section{Statistical analysis}

$$
\text { Inhibition } \%=\frac{(\text { No. of writhes }(\text { control })-N 0.0 \text { f writhes }(\text { Treated }))}{\text { No. of writhes }(\text { control })} \times 100
$$

Results of experiment were expressed as mean \pm SEM. Statistical analysis was performed using one-way ANOVA followed by Dunette's multiple comparison test using graph pad prism (version-9). The values of $p<0.05$ was considered as statistically significant.

\section{RESULTS}

\section{Phytochemical screening}

Table 2. Preliminary phytochemical screening of the extracts of $C$. sativum revealed the presence of glycosides, sterols, flavonoids, alkaloids, tannins and saponin

\begin{tabular}{|c|c|c|}
\hline S. $\mathbf{N}$ & Test & Result \\
\hline 1 & Glycoside & + \\
\hline 2 & Sterol & + \\
\hline 3 & Flavonoids & + \\
\hline 4 & Alkaloids & ++ \\
\hline 5 & Tannin & ++ \\
\hline 6 & Saponin & + \\
\hline 7 & Carbohydrates & + \\
\hline
\end{tabular}

Eddy's hot plate method
Table 3. Effect of ethanolic extract of Coriandrum sativum on heat induced pain (hot plate) in mice (All values are expressed as Mean \pm SD. The differences are significant at ${ }^{*} p<0.05$ when analyzed by one-way ANNOVA followed by Dunette's multiple comparison test)

\begin{tabular}{|c|c|c|c|c|}
\hline \multirow[t]{2}{*}{ Group } & \multicolumn{4}{|c|}{ Mean Reaction Time } \\
\hline & $30 \mathrm{~min}$ & $60 \mathrm{~min}$ & $90 \min$ & $120 \mathrm{~min}$ \\
\hline Negative control & $3.82 \pm 0.290$ & $4.27 \pm 0.178$ & $3.99 \pm 0.219$ & $3.89 \pm 0.430$ \\
\hline $\begin{array}{l}\text { Standard (Diclofenac sodium } 10 \\
\mathrm{mg} / \mathrm{kg} \text { ) }\end{array}$ & $7.22 \pm 0.355^{* * *}$ & $10.37 \pm 0.239^{* * *}$ & $15.74 \pm 0.775^{* * *}$ & $3.89 \pm 0.430$ \\
\hline Leaf extract Test-1 $(100 \mathrm{mg} / \mathrm{kg})$ & $4.22 \pm 0.186$ & $8.84 \pm 0.400^{* * * *}$ & $12.15 \pm 0.161^{* * *}$ & $10.23 \pm 0.179 * * *$ \\
\hline Leaf extract Test-2 $(500 \mathrm{mg} / \mathrm{kg})$ & $7.85 \pm 0.137^{* * *}$ & $12.23 \pm 0.517^{* * *}$ & $15.08 \pm 0.091^{* * *}$ & $13.07 \pm 0.148^{* * *}$ \\
\hline T 1 (100 most & $4.15 \pm 0.172$ & $8.33 \pm 0.548$ & $9.41 \pm 0.136^{* * *}$ & $38 * * *$ \\
\hline Seed extract Test-2 $(500 \mathrm{mg} / \mathrm{kg})$ & $7.24 \pm 0.081^{* * *}$ & $11.96 \pm 0.139 * * *$ & $13.12 \pm 0.235 * * *$ & $11.50 \pm 0.166^{* * *}$ \\
\hline
\end{tabular}

\section{Acetic Acid induced pain}

Table 4. Effect of Ethanolic extract of Coriandrum sativum acetic acid induced pain in mice

\begin{tabular}{|c|c|c|c|c|c|c|}
\hline \multirow[t]{2}{*}{ Group } & \multicolumn{6}{|c|}{ No. of writhing } \\
\hline & $5 \min$ & $10 \mathrm{~min}$ & $15 \mathrm{~min}$ & $20 \mathrm{~min}$ & $25 \mathrm{~min}$ & $30 \mathrm{~min}$ \\
\hline Negative control & $11.8 \pm 0.955$ & $11.2 \pm 0.593$ & $10.2 \pm 1.585$ & $12.2 \pm 1.308$ & $12.0 \pm 1.265$ & $10.2 \pm 1.585$ \\
\hline $\begin{array}{l}\text { Standard } \\
\text { (Diclofenac sodium } \\
10 \mathrm{mg} / \mathrm{kg} \text { ) }\end{array}$ & $3.2 \pm 0.593$ & $3.4 \pm 0.456$ & $3.6 \pm 0.829$ & $2.6 \pm 0.607$ & $4.0 \pm 0.632$ & $4.2 \pm 0.867$ \\
\hline $\begin{array}{l}\text { Leaf extract Test- } \\
(100 \mathrm{mg} / \mathrm{kg})\end{array}$ & $9.4 \pm 0.669$ & $8.8 \pm 0.867$ & $9.0 \pm 1.720$ & $9.2 \pm 1.035$ & $7.4 \pm 1.345^{*}$ & $8.6 \pm 0.456^{*}$ \\
\hline $\begin{array}{l}\text { Leaf extract Test-2 } \\
(500 \mathrm{mg} / \mathrm{kg})\end{array}$ & $5.8 \pm 0.522 * * *$ & $6.0 \pm 0.400^{* * *}$ & $6.2 \pm 0.769^{* * *}$ & $7.2 \pm 0.716 \mathrm{~ns}$ & $7.8 \pm 0.438 * * *$ & $7.8 \pm 0.996 \mathrm{~ns}$ \\
\hline $\begin{array}{l}\text { Seed extract Test } 1 \\
(100 \mathrm{mg} / \mathrm{kg})\end{array}$ & $10.2 \pm 0.912$ & $10.2 \pm 0.716$ & $7.8 \pm 0.657^{*}$ & $10.8 \pm 0.522$ & $9.2 \pm 0.769$ & $6.6 \pm 1.513^{*}$ \\
\hline $\begin{array}{l}\text { Seed extract Test-2 } \\
(500 \mathrm{mg} / \mathrm{kg})\end{array}$ & $7.2 \pm 0.522^{* *}$ & $7.2 \pm 0.593^{* *}$ & $6.6 \pm 0.963^{* *}$ & $8.0 \pm 0.632 * *$ & $6.0 \pm 1.166$ & $5.2 \pm 0.769^{* *}$ \\
\hline
\end{tabular}

(Results are expressed as mean \pm SEM from observation as compared to control group by one-way ANOVA followed by Dunette's multiple comparison test. Significant at $* p<0.05$ )

\section{DISCUSSION}

The present study revealed that the seeds and leaves of $C$. sativum possess analgesic effect. The hot plate method is one of the widely used methods for evaluation of analgesic effect and has been validated for use with both rats and mice. Therefore, we chose this test in addition with acetic acid induced writhing test to investigate the analgesic potential of ethanolic extract of Coriandrum sativum leaves and seeds. The analgesic effect of ethanolic extract of seeds and leaves was comparable to diclofenac.

In previous study, the analgesic effects of the aqueous extract of the seeds of Coriandrum sativum had been reported using hot plate and tail flick tests. ${ }^{17}$

The chemical compound responsible for the analgesic effect of the extracts could not be identified in the present study and needs to be studied in future. However, the presence of the 
flavonoids such as quercetin has been reported. ${ }^{18}$ It has been shown that the flavonoids have considerable analgesic and anticonvulsant effects. ${ }^{19}$ Sedative, CNS depressant and analgesic effects of flavonoids such as quercetin has been attributed to the affinity for the central benzodiazepine receptors. ${ }^{20,21}$ The beneficial effect of linalool in pentyletelrazole seizure models as well as its analgesic effects has been suggested. ${ }^{22,23}$

It can be suggested that the beneficial effects of the extracts which were observed in the present study are at least in part due to linalool which is a main compound in coriander. ${ }^{24}$ Analgesic effects of polyphenols including rutin, caffeic acid and gallic acid has also been reported which can be isolated from Coriandrum sativum. ${ }^{25}$

Each of these compounds may also have a role in the analgesic effects of the extracts which were seen in present study however it needs to be investigated more.

This study has few limitations analgesic activity of plant parts (seeds and leaves) was studied in acute condition but not in chronic condition due to lack of time and feasible methodology. Active components responsible for the analgesic activity were not isolated and identified due to lack of instruments. Apart from this there is no foreseen limitation of the study. Limitations encountered during the conduct of the study will be addressed accordingly. The main strength of this study is to compare the analgesic effect of plant extract with the standard drug.

\section{CONCLUSION}

The qualitative phytochemical study reveals the presence of sterols, carbohydrates, flavonoids, glycosides, tannins, alkaloids and saponins. The present study demonstrated that the ethanolic extract of seeds and leaves of Coriandrum sativum possess analgesic activity. The above effects may be due to the presence of flavonoids, linalool, borneol, camphor, tannins and sterols in the extracts.

\section{CONFLICT OF INTEREST}

None

\section{REFERENCES}

1. Pathan A, Kothawade K, Logade. Anxiolytic and analgesic effect of seeds of Coriandrum sativum Linn. International Journal of Research in Pharmacy and Chemistry 2011;1:108799.

2. Tunon H, Olavsdotter C, Bohlin LJJoE. Evaluation of antiinflammatory activity of some Swedish medicinal plants. Inhibition of prostaglandin biosynthesis and PAF-induced exocytosis. Journal of Ethinopharmacology. 1995;48(2):61-76.
3. Stucky CL, Gold MS, Zhang XJ. Mechanisms of pain Proceedings of the National Academy of Sciences of the United States of America. 2001;98(21):11845-6.

4. Pasternak G. Preclinical pharmacology and opioid combinations. Pain Medicine. 2012;13(suppl_1):S4-S11.

5. Trautmann M, Peskar BM, Peskar B. Aspirin-like drugs, ethanol-induced rat gastric injury and mueosal eicosanoid release. European Journal of Pharmacology. 1991;201(1):53-8.

6. Dharmasiri M, Jayakody J, Galhena G, Liyanage S, Ratnasooriya WJJoe. Anti-inflammatory and analgesic activities of mature fresh leaves of Vitex negundo. Journal of Ethinopharmacology. 2003;87(2-3):199-206.

7. Gupta M, Mazumder U, Gomathi P, Selvan, medicine a. Antiinflammatory evaluation of leaves of Plumeria acuminata. BMC Complementry and Alternative Medicine. 2006;6(1):1-6.

8. Singh P, Shrivastava AK, Kumar S, Dwivedi. Formulation and evaluation of sustained release matrix tablets of aceclofenac. Borneo Journal of Pharmacy. 2021;4(2):99-109.

9. Chen Y, Tao S, Zeng F, Xie L, Shen Z. Antinociceptive and antiinflammatory activities of Schefflera octophylla extracts. Journal of Ethinopharmacology. 2015;171:42-50.

10. Laribi B, Kouki K, M'Hamdi M, Bettaieb T. Coriander (Coriandrum sativum L.) and its bioactive constituents. Phytotherapia. 2015;103:9-26.

11. Zhang C-R, Dissanayake AA, Kevseroğlu K, Nair M. Evaluation of coriander spice as a functional food by using in vitro bioassays. Food Chemistry. 2015;167:24-9.

12. Eidi M, Eidi A, Saeidi A, Molanaei S, Sadeghipour A, Bahar M. Effect of coriander seed (Coriandrum sativum L.) ethanol extract on insulin release from pancreatic beta cells in streptozotocin-induced diabetic rats. Phytotherapy Research. 2009;23(3):404-6.

13. Yadav CK, Poudel K, Mehta R, Shrivastava AK. Antidepressant activity of the leaves of Zanthoxylum Armatum on Swiss albino mice. Journal of Universal College of Medical Sciences. 2020;8(02):46-50.

14. Shrivastava AK, Thapa S, Shrestha L, Mehta RK, Gupta A, Koirala N. Phytochemical screening and the effect of Trichosanthes dioica in high-fat diet induced atherosclerosis in Wistar rats. Food Frontiers. 2021.

15. Patel D, Desai S, Devkar R, Ramachandran A. Acute and subchronic toxicological evaluation of hydro-methanolic extract of Coriandrum sativum L. seeds. EXCLI Journal 2012;11:566.

16. Acimovic MG, Korac J, Jacimovic G, Oljaca S, Djukanovic L, Vesna V. Influence of ecological conditions on seeds traits and essential oil contents in anise (Pimpinella anisum L.). Notulae Botanicae Horti Agrobotanici Cluj-Napoca. 2014;42(1):232-8.

17. Taherian AA, Vafaei A, Rashidipour A, Emami AM, Miladi GH, Jarahi M. Effects of aqueous extract of seed of Coriandrum 
sativum on acute pain in mice. Journal of Medicinal Plants 2005,4;36-44

18. Kunzemann J, Herrmann K. Isolation and identification of flavon (ol)-O-glycosides in caraway (Carum carvi L.), fennel (Foeniculum vulgare Mill.), anise (Pimpinella anisum L.), and coriander (Coriandrum sativum L.), and of flavon-C-glycosides in anise. I. Phenolics of spices. Z Lebensm Unters Forsch. 1977;164(3):194-200.

19. Rylski M, Duriasz-Rowińska H, Rewerski W. The analgesic action of some flavonoids in the hot plate test. Acta Physiologica Polonica. 1979;30(3):385-8.

20. Kaur R, Singh D, Chopra K. Participation of $\alpha 2$ receptors in the antinociceptive activity of quercetin. Journal of Medicinal Food. 2005;8(4):529-32.

21. Medina JH, Viola H, Wolfman C, Marder M, Wasowski C, Calvo D. Overview flavonoids: a new family of benzodiazepine receptor ligands. Neurochemical Research. 1997;22(4):419-25.

22. Peana AT, Paolo SD, Chessa ML, Moretti MD, Serra G, Pippia P. $(-)$-Linalool produces antinociception in two experimental models of pain. European Journal of Pharmacology. 2003;460(1):37-41.

23. Peana AT, Rubattu P, Piga GG, Fumagalli S, Boatto G, Pippia P. Involvement of adenosine $\mathrm{A} 1$ and $\mathrm{A} 2 \mathrm{~A}$ receptors in (-)linalool-induced antinociception. Life Sciences. 2006;78(21):2471-4

24. Usta J, Kreydiyyeh S, Knio K, Barnabe P, Bou-Moughlabay Y, Dagher. Linalool decreases HepG2 viability by inhibiting mitochondrial complexes I and II, increasing reactive oxygen species and decreasing ATP and GSH levels. Chemicobiological Interactions. 2009;180(1):39-46.

25. Kubo I, Fujita K-i, Kubo A, Nihei K-i, Ogura T. chemistry f. Antibacterial activity of coriander volatile compounds against Salmonella choleraesuis. International Journal of Research in Pharmacy and Chemistry. 2004;52(11):3329-32. 